Columbia Law School

Scholarship Archive

1995

\title{
The World Trade Organization's Agreement on Government Procurement: Expanding Disciplines, Declining Membership?
}

\author{
Bernard Hoekman \\ European University Institute, Robert Schuman Centre for Advanced Studies (RSCAS), \\ bernard.hoekman@eui.eu
}

Petros C. Mavroidis

Columbia Law School, petros.mavroidis@unine.ch

Follow this and additional works at: https://scholarship.law.columbia.edu/faculty_scholarship

Part of the Antitrust and Trade Regulation Commons, and the International Trade Law Commons

\section{Recommended Citation}

Bernard Hoekman \& Petros C. Mavroidis, The World Trade Organization's Agreement on Government Procurement: Expanding Disciplines, Declining Membership?, WoRLD BANK POLICY RESEARCH WORKING PAPER No. WPS1429 (1995).

Available at: https://scholarship.law.columbia.edu/faculty_scholarship/2398

This Working Paper is brought to you for free and open access by the Faculty Publications at Scholarship Archive. It has been accepted for inclusion in Faculty Scholarship by an authorized administrator of Scholarship Archive. For more information, please contact scholarshiparchive@law.columbia.edu. 


\section{Policy Research Working Paper}

The World Trade

Organization's Agreement on Government

Procurement

Expanding Disciplines,

Declining Membership?

Bernard M. Hoekman

Petros C. Mavroidis

The World Bank

Europe and Central Asia, and Middle East and North Africa

Technical Department

Private Sector and Finance Team

March 1995

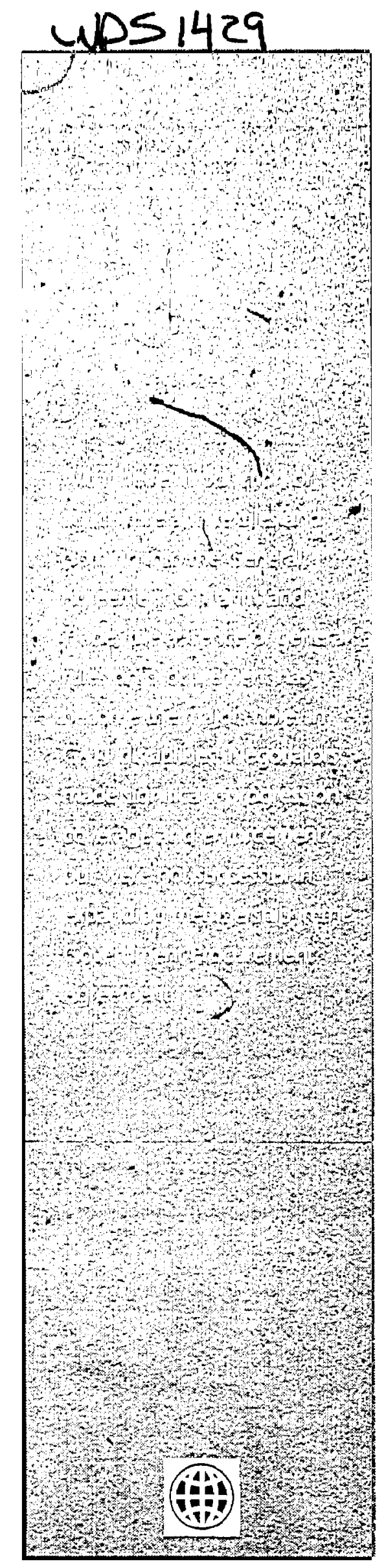




\section{Summary findings}

Hoekman and Mavroidis analyze the new Government Procurement Agreement (GPA) that was negotiated between a subset of General Agreement on Tariffs and. Trade (GATT) members in the Uruguay Round, focusing especially on the expansion of coverage to services and on the strengthening of enforcement mechanisms.

Coverage objectives were substantially achieved, although commitments contain many exceptions for services. The transparency of signatories' procurement practices was enhanced and enforcement provisions were strengthened, particularly by the introduction of a bidprotest challenge mechanism, which allows private parties (firms) to invoke the Agreement before national courts. (A potential problem: domestic courts could produce divergent interpretations of the GPA.)

Unlike most of the other Tokyo Round codes - for example, the agreements on technical barriers to trade (standards), import licensing, customs valuation, subsidies, and antidumping - the GPA could not be "multilateralized." Its disciplines apply only to World Trade Organization (WTO) members that have signed it. Public procurement represents a major source of demand for goods and services in most countries. Getting domestic procurement policies "right" can therefore have major effects on welfare. And improving developing countries' arcess to global procurement markets could help induce governments to adopt multilateral rules, if those could be shown to be in their interests.

Hoekman and Mavroidis explore why only a limited number of countries have signed the GPA. They suggest the pursuit of tariffication as one avenue through which the Agreement might be expanded to cover all WTO members. In the process, the GPA could be improved economically by eliminating current provisions that allow for measures with quota-like effects, and by weakening incentives to seek "absolute" sector-by-sector reciprocity.

This paper - a product of the Private Sector and Finance Team, Europe and Central Asia, and Middle East and North Africa Regicns, Technical Department - is part of a larger effort in the department to monitor agreements of interest to the region. Copies of the paper are available free from the World Bank, $1818 \mathrm{H}$ Street NW, Washington, DC 20433. Please contact Ms. Faten Hatab, room H8-087, extension 38535 (22 pages). March 1995.

The Policy Research Working Paper Series disseminates the findings of work in progress to encourage the exchange of ideas about development issues. An abjective of the series is to get the findings onat quickly, even if the presentations are less than fully polished. The papers cany the names of the authors and should be used and cited accordingly. The findings, interpretations, and conclusians are the authors' oum and should not be attributed to the World Bank, its Executive Board of Directors, or any of its member countries. 


\section{The WTO's Agreement on Government Procurement: Expanding Disciplines, Declining Membership?"}

Bernard M. Hoekman

World Bank and CEPR

1818 H St. N.W.

Washington DC 20433

Tel: 12024731185
Petros C. Mavroidis

GATT Secretariat

154 Rue de Lausanne

CH 1211 Geneva 21

Tel: 41227395143

Keywords: government procurement, multilateral agreements, trade policy. JEL classification: F13, H57.

- We are grateful to Annet Blank and Adrian Otten for helpful discussions when writing this paper. Our thanks as well to Aaditya Mattoo for insightful comments on an earlier draft. The views expressed are personal and should not be attributed to the World Bank or the GATT Secretariat. 


\section{Summary}

The Agreement on Government Procurement (GPA)--originally negotiated during the Tokyo Round--was renegotiated for the second time during the Uruguay Round. It is one of the WTO's socalled Plurilateral Agreements, in that its disciplines apply only to those WTO Members that have signed it. In contrast to most of the other Tokyo Round codes--e.g., the agreements on technical barriers to trade (standards), import licensing, customs valuation, subsidies, and antidumping--the GPA could not be 'multilateralized'. With the reintroduction of agriculture and textiles and clothing into the GATT, procurement has therefore become the major 'hole' in the coverage of the GATT.

The main objective of the GPA has always been--and remains--to subject government procurement to international competition. To accomplish this objective, the Tokyo Round GPA extended the GATT obligations of national treatment, MFN and transparency to the tendering procedures of government entities. The trade-off for such far-reaching obiigations, however, was a restrictive coverage, insofar as the GPA applies only to those entities included on the schedules submitted by signatory nations. The renegotiation of the GPA during the Uruguay Round focused on further expansion of its coverage, strengthening of its enforrement provisions, and addressing the factors perceived by developing countries that inhibited them rom signing the Agreement. These constraints related both to the substantive provisions of the GPA and to the 'conditionality' imposed by members concerning the entity offers made by nonsignatories when negotiating accession. The main objectives in terms of coverage were to extend the entity coverage to include sub-central and quasi-governmental bodies, and to cover procurement of telecommunications, heavy electrical and transportation equipment, as well as government purchases of services.

Negotiators made significant progress with respect to coverage and enforcement, but were not successful in expanding membership. The coverage objectives were substantially achieved, although commitments contain many derogations regarding services. Enforcement provisions were strengthened, in particular by the introduction of a bid-protest challenge mechanism. These are very innovative for the GATT-MTN system in that they allow private parties (firms) to invoke the GPA before national courts. In the process, however, potential problems have been created, due to the possibility of diverging interpretations of the GPA by domestic courts. Much was done to enhance transparency of procurement practices of signatories, although further strengthening could be achieved by requiring that the publication of contract awards (already required) include a brief motivation of decisions (presently not required).

Membership of the GPA remains limited. Indeed, at the entry into force of the new GPA there may be fewer signatories than at the beginning of the Uruguay Round. Two of the Parties to the Tokyo round code did not sign the new GPA. Inducing greater participation through 'multilateralization' of the GPA is the main challenge facing policymakers. Public procurement constintes a large source of demand for goods and services in most countries. Getting domestic procurement policies 'right' therefore can have large welfare effects. At the same time, improving developing country access to global procurement markets could help to induce Government's to adopt multilateral rules if these can be shown to be in their interests. Perhaps the most immediate source of urgency stems from a provision in the General Agreement on Trade in Services (GATS), which calls for negotiations on government procurement of services to be initiated within two years of the entry into force of the WTO (i.e., by January 1997). The rules and procectures that are negotiated will be important in determining the potential for growth in developing country exports of services. 
Pursuit of tariffication could be an avenue through which membership in the GPA can be expanded in the future. In the process, the GPA could be improved from an economic perspective by eliminating current provisions that allow for measures with quota-like effects, and weakening the incentives to seek 'absolute' reciprocity on a sector-by-sector basis. More generally, research efforts are required to identify possible approaches towards extending multilateral disciplines for procurement of goods and services that will be beneficial to developing countries, and thus be helpful in formulating negotiating positions and strategies. Such research should analyze in greater depth the economics of the GPA's rules and disciplines, investigate what the impact of the Agreement has been, expand the knowledge of current procurement policies in non-member countries, and quantify the importance of procurement markets in major selected OECD and developing countries. 


\section{Introduction}

The Agreement on Government Procurement--originally negotiated during the Tokyo Round-was renegotiated for the second time during the Uruguay Round. The new Government Procurement Agreement (GPA), signed in Marrakesh on April 15, 1994, will enter into force on January 1, 1996. It is one of the WTO's so-called 'Annex IV' or Plurilateral Agreements, in that its disciplines apply only to those WTO Members that have signed it.' In contrast to most of the other Tokyo Round codes-e.g., the agreements on technical barriers to trade (standards), import licensing, customs valuation, subsidies, and antidumping-the GPA could not be 'multilateralized'. With the reintroduction of agriculture and textiles and clothing inco the GATT, procurement has therefore become the major 'hole' in the coverage of the GATT. ${ }^{2}$

The main objective of the GPA has always been-and remains-to subject government procurement to international competition. ${ }^{3}$ To accomplish this objective, the Tokyo Round GPA extended the GATT obligations of national treatment, MFN and transparency to the tendering procedures of government entities. The trade-off for such far-reaching obligations, however, was a resurictive coverage, insofar as the GPA applied only to those entities included on the schedules submitted by signatory nations. While the entity coverage was somewhat limited initially, it was contemplated that more entities would be added as the result of the periodic renegotiations called for in the Agreement.

Given the sensitive nature of procurement decisions and a tradition of buy national policies prevalent in many signatories, it is not surprising that during the first few years of implementation sigr atories notified numerous instances of noncompliance in GATT Committee meetings. Inadequacies in publishing tender notices, maintaining response deadlines too short for bid submissions, and not notifying unsuccessful bidders were some of the issues that were discussed. Although some of these problems were of a start-up nature, practices found objectionable to certain countries appeared with some regularity on the agenda of Committee meetings. Examples included the use of noncompetitive procurement procedures such as single tendering (asking only one firm to submit a bid) and the practice by some countries of splitting large contracts into smaller lots so as to fall below the threshold minimum

1/ Membership of the GPA is only open to WTO Members. Signatories to the new GPA are Austria, Canada, the EU, Finland, Israel, Japan, Korea, Norway, Sweden, Switzerland, and the United States.

2/ There are four plurilateral agreements: the GPA, the civil aircraft agreement, and the arrangements on bovine meat and dairy products. As the civil aircraft agreement encompasses most producers, the lack of multilateralization has no serious implications. See Jackson (1989) and Hoekman and Stern (1993) for a discussion of the codes.

3/ See Bourgeois (1982) and Hoekman and Stern (1993) for a description and discussion of the Tokyo Round Agreement. The following paragraphs draw in part from Hoekman and Stern (1993). 
specified in the code. Because noncompliance is often difficult to detect, there are inherently problems in monitoring the implementation of the GPA and enforcing its rules. Of particular importance was the absence of a timely bid protest mechanism in the Tokyo round code, or an adequate remedy if a GATT dispute settlement panel were to find in the favor of a complainant.

The GPA initially exempted purchases with a value of less than Special Drawing Rights (SDR) 150,000. This was lowered to SDR 130,000 during the first renegotiation of the GPA--initiated in 1983, with the results entering into force in February 1988. The amended 1988 Agreement also extended coverage to rental and leasing contracts, increased the time allowed for bid submission, and required the publication of information on winning bids. The second renegotiation of the GPA during the Uruguay Round focused on further expansion of its coverage, strengthening of its enforcement provisions, and addressing the factors perceived by developing countries that inhibited them from signing the Agreement. These constraints related both to the substantive provisions of the GPA and to the 'conditionality' imposed by members concerning the entity offers made by nonsignatories when negotiating accession. The main objectives in terms of coverage were to extend the entity coverage to include sub-central and quasi-governmental bodies, and to cover procurement of telecommunications, heavy electrical and transportation equipment, as well as government purchases of services. Negotiators made significant progress with respect to coverage and enforcement, but were not successful in expanding membership.

The objective of this paper is to provide an analysis of the new GPA, taking both a legal and policy perspective. Section II provides a succinct description of the main provisions of the new GPA, highlighting major differences with the 1988 Agreement. ${ }^{4}$ Section III discusses the new GPA's most innovative feature: its enforcement and dispute settlement provisions. Section IV turns to the issue of why membership of the GPA remains so limited; indeed, it actually declined as two countries-Hong Kong and Singapore-have not signed it. Section V concludes.

\section{The GPA}

The objectives of the GPA are stated in the Preamble: contribute to greater liberalization and expansion of world trade; eliminate discrimination among foreign products/services or foreign suppliers; and enhance the transparency of relevant laws and practices. The Tokyo Round Agreement included a provision (Article IX:6(b)) that called for periodic negotiations to broaden and improve the GPA on the basis of mutual reciprocity. Article IX:6(b) explicitly called for the Committee on Government Procurement (the Committee hereafter) to explore at an early stage the possibilities of expanding the

4/ Blank (1994) and Messerlin (1994) are complementary sources. 
coverage of the Agreement to include service contracts.' A significant broadening of the Agreement was achieved during the Uruguay round. Services and construction became subject to the GPA, and the reach of the Agreement was extended to sub-central entities.

Article I (Scope and Coverage) states that "this Agreement applies to any law, regulation, procedure, or practice regarding any procurement by entities covered by this Agreement, as specified in Annexes 1-5." The concept of 'procurement' covers all contractual options, including purchase, leasing, rental and hire-purchase, with or without the option to buy. The GPA uses a so-called positive list approach to determine the reach of the Agreement: it applies only to entities that are listed in an Annex. There are three 'entity Annexes': Annex 1 lists covered central government entities; Annex 2 lists subcentral government entities; and Annex 3 lists "all other entities that procure in accordance with the provisions of this Agreement." Annex 3 is a catch-all category, that includes bodies such as utilities. Its careful wording allows for the fact that entities that are listed may be partially or totally private. Indeed, it is noteworthy that the term entity is nowhere defined, reflecting the fact that there was no consensus on what constitutes a 'public undertaking'. Instead of attempting to agree on a common definition, a decision was made to maintain significant flexibility regarding the entities that could be put on the table (Messerlin, 1994). ${ }^{6}$ Article I:3 operates as an anti-circumvention provision: if scheduled entities require ${ }^{7}$ enterprises not covered to award contracts in accordance with particular requirements, the two basic nondiscrimination principles (national treatment and MFN) apply mutatis mutandis.

The entities that are listed in the three Annexes are subject to the rules and disciplines of the GPA with respect to their procurement of goods and services if: (1) the value of the procurement exceeds certain specified thresholds; $;^{8}$ and (2) the goods or services that are involved are not exempted from the coverage of the Agreement. Table 1 sets out the various thresholds that apply to the procurement of goods and services for the three types of entities for each of the Parties to the GPA. Note that there is some variance between signatories. Only for central government ent:.ies is there a common minimum threshold of SDR 130,000 for goods and non-construction services. Thresholds can be as high as SDR

5/ The Committee is composed of representatives from the parties to the GPA. It provides a forum for the exchange of information and views, and is the body to which disputes are initially brought.

6/ Article XXIV:6(b) allows for the removal of entities included in one of the Annexes subsequent to "the effective elimination of government control or influcnce" over the entity. The most common way this might occur is through privatization. If there is an objection to the removal, dispute settlement procedures may be invoked. Signatories may explicitly exclude procurement made by entities if there is competition. Thus, e.g., Japan has stated in its Annex that "This Agreement shall not apply to contracts which the entities award for purposes of their daily profit making activities which are exposed to competitive forces in markets."

7/ This term has not been interpreted by a GPA dispute settlement panel, but it seems safe to conclude that it should be interpreted strictly.

8/ Valuation is to take into account fees, premia, commissions, and indirect taxes. In the case of the EU a fictive VAT rate of 13 percent must be included (Messerlin, 1994). 
15 million for construction services for non-central government entities. ${ }^{9}$ The product coverage of the Agreement is also determined by the Annexes. As far as goods are concerned, in principle all procurement is covered, unless specified otherwisc in an Annex. Thus, a negative list approach is used to determine the coverage of the GPA for procurement of non-defense related goods by scheduled entities. $^{10}$ The procurement of goods by Defence Ministries or similar entities is often subject to a positive list: only items explicitly scheduled are covered. Procurement of services is also subject to a positive list: only the procurement by covered entities of services explicitly scheduled in Annexes 4 and 5 are subject to the GPA's rules, and then nnly insofar as no qualifications or limitations are maintained in the relevant Annexes.

Many Parties have made explicit derogations to the commitments that are contained in their Annexes. These can be divided into two types. The first consists of derogation from the GPA's nondiscrimination requirement contained in Article IIl. These have been made by the majority of signatories. They generally specify that Party $X$ will not follow the GPA's nondiscrimination rule to the procurement by entities listed in Annex $Y$ to firms originating in Party $R, S$, or $T$ "until such time as $X$ has accepted that the Parties concerned give comparable and effective access for $X$ s undertakings to the relevant markets. Note that this reflects an explicit requirement of absolute reciprocity on either a product/service and/or an entity basis. The second type of derogation pertains to commitments on services (Annexes 4 and 5), and specifies that services that are listed are covered only to the extent that other Parties to the GPA have provided reciprocal access to that service. Canada, Finland, Korea, Switzerland and the United States have made such derogations. The mix of positive and negative list approaches for entities and products/services, varying thresholds, and the use of exceptions and derogations makes it difficult to ascertain the effective scope of the GPA.

\section{Basic Principles}

The two basic principles governing the GPA are non-discrimination and national treatment (Article III). The way these two principles have traditionally been understood in the GATT-context is that the former refers to a legal prohibition to discriminate between foreign products; in the GPA-context, the ratione personae-component of the obligation stays the same, whereas the ratione materiae-component

9/ It should also be noted that the Annexes of individual signatories may specify higher thresholds for particular members of the GPA in an attempt to ensure reciprocity. For example, although the threshold for construction services is SDR 5 million for the United States, the U.S. maintains a SDR 15 million threshold for Korean firms.

10/ To give some illustrations, Austria, Canada, the EU, Finland, Norway, Sweden exclude procurement of agricultural products made in the context of agricultural support programs; the EU and Swizzerland exempt contracts by Annex 1 or 2 entities relating to drinking water, energy, transport and telecommunications; Israel has exempted the procurement of a number of goods by its Ministry of Health; Japan has excluded procurement of public electrical telecommunications equipment by Arnex 3 entities; Korea excludes procurement of satellites for five years; etc. 
is extended to cover also a positive list of services and suppliers of products and/or services. The latter refers to a legal prohibition to discriminate, with respi .t to the aforementioned categories, between foreign and domestic sources. The two fundamental obligations apply irrespective of the customs treatment of the products or services that will affect the procurement contract. Article III:3 of the GPA states to this effect that the aforementioned provisions "shall not apply to customs duties and charges of any kind imposed on or in connection with importation, the method of levying such duties and charges, other import regulations and formalities, and measures affecting trade in services other than laws, regulations, procedures and practices regarding government procurement covered by this Agreement".

Article III:2 further states that each Party "shall ensure" that its entities do not discriminate between locally-established suppliers "on the basis of degree of foreign affiliation or ownership" or "on the basis of the country of production of the good or service being supplied". Article III::. is new. The old Agreement spoke only of traded goods, i.e., products originating within the customs territory (including free zones) of Parties. Under the new GPA, the words "originating within .." were deleted from III: 1 , implying that it implies to both trade and sales through establishment. Contrary to first appearances, the addition of Article $\mathrm{III:2}$ is not redundant, however. A rationale for the inclusion of Article III:2 may be that the GATT does not have any agreed rules to determine the origin of locally established firms. By including a blanket prohibition on discrimination against locally established firms, the need for ascertaining origin disappears. Article III incorporates an obligation of result: signatories must ensure that the behavior of covered entities conforms with the nondiscrimination principles. The means of satisfying this obligation are not spelled out. Parties are free to choose whatever means they deem appropriate to achieve the agreed result. Inaction by signatories, as well as action to the contrary, gives adequate grounds to affected Parties for legal proceedings to be initiated.

Article III implies that policies such as offsets are prohibited insofar as they imply discrimination. This prohibition is stated explicitly in Article XVI, which forbids developed countries to use offsets. However, developing countries may continue to require offsets, as long as these are clearly defined, applied nondiscriminatorily, and are not used as a criterion in awarding contracts."

The Agreement provides for four methods of tendering (Articles VII and XIV): open, selective, limited or through competitive negotiations.

(i) Open tendering procedures: Any interested supplier may submit a tender. This is the preferred method. However, three other methods are also allowed for if a number of conditions have been fulfilled. These are:

11/ That is, they can be conditions that are specified in tender documentation, but a firm cannot be awarded a contract on the basis of exceeding the minimum offset requirement that is imposed. 
(ii) Selective rendering procedures: Only those suppliers invited to do so by the entity may submit a tender. Entities that desire to have recourse to these procedures should maintain lists of quajified suppliers that will be interested to bid. These lists basically establish eligibility criteria that have to be fulfilled by applicants that want to figure among the qualified suppliers. Signatories must publish at least once a year in an agreed publication the lists maintained, their validity, and the conditions to be satisfied for inclusion, including the methods used by entities to verify that requirements are met (Article $1 \mathrm{X}: 9$ ).

(iii) Limited tendering procedures: Under this method an entity contacts suppliers individually. Article XV of the GFA provides an exhaustive list of justifications for using limited tendering procedures (previously known as single tendering procedures). These include the absence of tenders in response to an open or selective tender, cases of urgency, additional deliveries by an original supplier, or additional construction services not included by intended to be within the original contract. Limited tendering procedures should not be used "with a view to avoiding maximum possible competition or in a manner which would constitute a means of discrimination among suppliers of other Parties or protection to domestic producers or suppliers".

(iii) Negotiated procedures: These may be conducted in the context of procurement in which entities have indicated their intent to do so, or when it appears from the evaluation that ne tender is obviously the most advantageous in terms of the specific evaluation criteria set forth in the notices or tender documentation. Elimination of participants in this context should be carried out in accordance with the criteria set forth in the tender documentation. In case of modification of the criteria, all remaining participants must be accorded an opportunity to submit new offers.

The GPA pays particular attention to ensuring and enhancing transparency. Article IX governs the opening of the procedures. According to this Article, each entity is obliged to publish an invitation to participate for all cases of intended procurement, except for the case of limited tendering. Summaries of procurement notices have to be issued in one of the WTO's official languages (English, French or Spanish). Notices of planned or proposed procurement must piuvide a list of all elements needed to ensure transparency, including the mode of procurement, its nature and quantity, dates of delivery, economic and technical requirements, amounts and terms of payment etc. In publication of notices (calls for tender), entities must make clear that procurement is covered by GPA. Article VI (Technical Specifications) requires that such specifications are not be adopted with the effect of creating unnecessary obstacles to international trade, and where appropriate be expressed in terms of performance rather than design or descriptive characteristics and be based on international standards where such exist. For tenders to be considered for award, they must comply at the time of the opening with the notices and the conditions of participation (Articl X XIII). While Article VI is not strongly worded--what is a 'necessary barrier' to trade; what is appropriate?--the challenge procedure discussed below gives this language some bite. 
Entities are legally obliged under the GPA (Article XIII:4b) to uward contracts to the tenderer who "lhas been determined to be fully capnble of undertaking the contract" and who is (a) either the lowest tender; or (b) the tender which in teims of the specific cvaluation criterin set forth in the notices or tender documentation is determined to be the most advantageous. The first of the two conditions to be fulfilled requires a tactual determination. Some margin of discretion by the procuring entities is allowed for in the sense that it involves, by definition, judgment by the procuring entities on the capacity of the tenderer to fulfill the contract. Determination of the lowest tender is in principle unambiguous. Who best meets the evaluation criteria is open to a considerable degree of discretion, however. The binding constraint is therefore the specific evaluation criteris set forth in the notices or tender documentation. It would be a violation of the Agreement were an entity to consider a tender as the most advantageous on the basis of evaluation criteria that were no: specified in the notices or tender documentation.

The foregoing requirements do not need to be followed if the procuring entity decides it is in the public interest not to issue the contract (Article XIII:4(b). This could prove to be an important loophole in the Agreement since the public interest is nowhere defined in the Agreement. The 'public interest' clause could allow industrial policy considerations to be pursued by simply delaying contracts or reformulating them to better suit domestic bidders. The 'public interest' provision, which echoes an identical provision in the old GPA, has never been interpreted in the GATT case-law. In part this may reflect the fact that entities have absolute discretion to formulate notices with respect ' 0 technical specifications within the limits of Article VI. In principle. technical specifications must be based on performance rather than descriptive criteria and on international standards where existing. But, this requirement is qualified by the words where appropriate (see above). This 'appropriateness-test' is another potential loophole in the GPA.

There is no obligation in the GPA to adequately motivate decisions. Such an obligation exists, for example, in other WTO Agreements (e.g., the Subsidies Agreement. The GPA contains two provisions that address this issue in substantially different ways. Article XVIII:2 states that: "Each entity shall, on request from a supplier of a Party, promptly provide: pertinent information concerning the reasons why the supplier's application to qualify was rejected, why its existing qualification was brought to an end and why it was not selected; and to an unsuccessful tenderer, pertinent information concerning the reasons why its tender was not selected and on the characteristics and relative advantages of the tender selected as well as the aame of the winning tenderer". Article XIX:2 provides that:

The government of an unsuccessful tenderer which is a Party to this Agreement may seek, without prejudice to the provisions under Article XXII, such additional information on the contract award as may be necessary to ensure that the procurement was made fairly and impartially. To this end, the procuring government shall provide information on both the characteristics and relative advantages of the winning tender and the contract price. Normally this latter information may be disclosed by the government of the unsuccessful tenderer provided 
it exercises this right with discretion. In cases where release of this information would prejudice competition in future tenders, this information shall not be disclosed except after consultation with and agreement of the party which gave the information to the government of the unsuccessful tenderer."

The need to motivate therefore becomes operative only upon a request of an unsuccessful tenderer or an intervention of his/her government to this effect. As the publication of the award of contracts required under the GPA merely has to identify the successful tenderer (without any motivation), justifications only need to be elaborated ex post facto following a formal request to this effect. This approach is at odds with GATT-Agreements on Subsidies or Antidumping and the GATT case-law in this context, which requires motivation of decisions. ${ }^{12}$

While entities must operate within the limits prescribed by the Agreement(s) (e.g., technical specifications have to be established ex ante), the choice of specifications is entirely the responsibility of the procuring entities. The only limit to their discretion is the obligation not to create "unnecessary obstacles to international trade" (Article VI:1). The question whether the choice of specifications is necessary or appropriate in order to achieve the desired outcome appears to escape judicial review, unless the obligation imposed by Article VI: 1 is interpreted in a wide manner.

\section{Enforcement}

There are many possibilities through which entities may attempt to avoid the GPA's obligations on a de facto basis. 'Classic' tactics in this regard that have been brought forward in past GPA Committee meetings are splitting of contracts to fall below the GPA's threshold, abuse of technical specifications, short deadlines, non-publication of calls for tender, and the use of limited tendering (Hoekman and Stern, 1993). Although the new GPA makes renewed efforts to reduce the scope for circumvention-e.g., through setting of deadl. «s; prohibiting splitting [Article II:3], and establishing detailed rules on the contents of tender documentation and the award of contracts-without an effective bid protest procedure such rules may not be very effective in operational terms.

An important innovation in the new GPA is therefore the introduction of a challenge procedure (Article XX). The nature of procurement is such that most of the time, unless rapid action can be taken, inconsistencies with the Agreement will de facto be tolerated as firms will not have an interest in bringing cases. The drafters of the new GPA attempted to address the need for bid-protest mechanisms (long on the agenda of negotiators) by the introduction of the challenge procedures. According to Article XX:7, "challenge procedures shall provide for:

12/ See for example the Panel report on "Korea-Antidumping Duties on Imports of Polyacetal Resins from the United States", ADP/92, adopted on 29 April 1993, \$209. 
(a) rapid interim measures to correct breaches or the agreement and to preserve commercial opportunities. Such action may result in suspension of the procurement process. However, procedures may provide that overriding adverse consequences for the interests concerned, including the public interest, may be taken into account in deciding whether such measures should be applied. In such circumstances, just cause for not acting shall be provided in writing;

(b) an assessment and a possibility for a decision on the justification of the challenge; and

(c) correction of the breach of the Agreement or compensation for the loss or damages suffered, which may be limited to costs for tender preparation or protest." 13

Viewed from a procedural/legal point of view this is a rare example in the WTO-system where private parties can invoke WTO-law before domestic courts. Article $\mathbf{X X}$ requires contracting parties to enact appropriate procedures in order to give effect to their assumed obligation; they have to guarantee that challenges will be heard by a court or by an impartial and independent body that will respect the minimum of due process (Article XX:6). ${ }^{14}$ This adjudication body however, whatever its form, is required to apply the GPA: this stems unequivocally from the cited Article XX:7 according to which the bodies will be required to provide rapid interim measures to correct breaches of the Agreement. Article $X X: 8$ specifies further that "with a view to the preservation of the commercial and other interests involved, the challenge procedure shall normally be completed in a timely fashion."

If viewed from the effectiveness/efficiency of remedies point of view, challenge procedures constitute a step forward. The challenge procedures provide what was missing from the previous Agreement, namely the possibility of speedy action against violations of GPA rules and disciplines. This is probably their main contribution. Even in cases where panels are bold enough to suggest "restitutio in integrum" as a remedy for illegally awarded contracts, there is always the possibility of excessive onerousness. Moreover, as a general rule, preventive action is, in principle, more effective than corrective action ex post.

There are possible negative implications however. These are related to the interpretation of the GPA: in principle, all signatories have been put in a position to interpret the Agreement in what could be divergent ways. Signatories of the GPA could provide the legal possibility to appeal at the domestic level against decisions in this context. Moreover, signatories always retain the possibility to bring a case before a GATT-panel if they believe that domestic courts have misinterpreted the GPA. To the extent

$13 /$ It should be noted that in their Annexes signatories may make derogations on the applicability of Article $\mathbf{x X}$.

$14 /$ If not a court, a review body must be subject to either judicial review or have procedures providing for hearings, representation, access to all proceedings, witnesses, written decisions and disclosure of documents. 
that GATT panel reports do not constitute binding precedents, nothing guarantees that a degree of homogeneity in the case law in this area will be preserved, and thus legal security. This problem could prove to be rather serious given that the basic object of the challenge procedures is to provide for timely remedies. Any non-challenge in this context could theoretically amount to tolerance of inconsistencies if the ruling of the Trondheim panel was adhered to in the future. ${ }^{\text {Is }}$ Consequently, much depends on the diligence and the good faith of the signaturies that put into place and apply the challenge procedures.

The GPA's dispute settlement procedures are contained in Article XXII. Basically, the original structure of consultations/panel procedures is preserved: recourse to panel procedures is an option if bilateral consultations fail to produce a satisfactory result. Article XXII:1 scates that "the provisions of the Understanding on Rules and Procedures Governing the Settlement of Disputes under the WTO Agreement... shall be applicable except as otherwise specifically provided". What follows will concentrate on the distinctive features of the GPA. Article XXII:2 recognizes two forms of legal complaints: violation complaints, where the object of the dispute is an alleged violation of the Agreement and non-violation complaints, where, notwithstanding the consistency of a particular measure with the Agreement, rights and benefits of signatories have been nullified or impaired. Thus, the third form of legal complaint known in the GATT legal system, the situation complaint, has been left out of the GPAcontext. This is a rather unimportant omission, since it is difficult to imagine complaints other than violation and non-violation. ${ }^{16}$

All requests for establishment of Panels will be forwarded to the Dispute Settlement Body (DSB), the WTO-organ responsible for establishing panels, adopting panel and Appellate Body reports, making recommendations or giving rulings on the matters before it, maintaining surveillance of implementation of rulings and recommendations, and authorizing suspension of concessions and other obligations. However, because the GPA is a 'plurilateral' agreement, members of the DSB are restricted to signatories of the GPA when addressing disputes arising under GPA auspices.

Although the procedures established in the WTO-Understanding on Dispute Settlement are applicable, an interesting particularity of the GPA concerns remedies. The WTO Understanding nowhere specifies applicable remedies, implying that all public international law remedies are applicable in the WTO-context. The GPA also refrains from specifying applicable remedies, so that all public international law remedies are applicable here as well. The GPA goes beyond the WTO-Understanding, however, by

15/ As discussed in Mavroidis (1993), in the Trondheim case the panel found that the procurement procedures that were employed violated the GPA. However, the panel also concluded that it was too late to remedy the situation and decided to accept an undertaking by Norway that the procedures that were followed would not be repeated in the future.

16) Situation complaints have never been pursued in the GATT-context. According to Petersmann (1991) they have fallen in desuetude. Only in one instance has there been a threat of bringing a situation complaint before a panel (EC v. Japan), see Hoekman and Mavroidis (1994). 
stating that the DSB shall have, inter alia, the competence to authorize "consultations regarding remedies when withdrawal of measures found to be in contravention of the Agreement is not possible" (Article XXII:3). This provision appears to have been introduced because of the dissatisfaction of some signatories with the panel ruling on the Trondheim case on remedies. While panels could nomally be expected to decide on the appropriateness of a particular remedy taking into account the facts of the case, here the initiative is explicitly delegated to the parties to the dispute. It is difficult to justify this shift of initiative on legal grounds, especially given that public international law remedies are not circumscribed at all.

Article 3:7 of the WTO-Understanding states that "in the absence of a mutually agreed solution, the first objective of the dispute settlement mechanism is usually to secure the withdrawal of the measures concerned ir these, are found to be inconsistent with the provisions of any of the covered agreements". ${ }^{17}$ Article 3:7 reproduces a provision of the 1979 Understanding on Dispute Settlement. Although this constituted a description of the 'state of the art' at that point in time, the WTO-Understanding is not an agreed description of what customarily has happened in panel procedures. Since 1979 a number of panels have gone beyond the 'usual' ex nunc GATT-remedy. 'Usual' remedies have been suggested in the majority of the cases, but other, types of remedies have been recommended as well (e.g., reimbursement). It is nowhere implied that 'unusual' remedies create a presumption of inconsistency. Since the Trondheim case, a number of signatories have revealed their dissatisfaction with panel rulings that were limited to ex nunc remedies in the GPA-context, presumably because of their ineffectiveness. Additionally, members of the GPA can reach mutually acceptable, bilaterally negotiated solutions (see above) that, in principle, can also go beyond the 'usual' remedy. It appears therefore that WTO-members did not want to state explicitly what implicitly is already within the realm of competence of WTOadjudicating bodies with respect to remedies.

The provision allowing far bilaterally negotiated remedies could prove to be very interesting if viewed as evidence of state practice in the field of remedies. Since the WTO-Understanding is applicable if not superseded by the provisions of the GPA, an assessment of the legal value of such bilateral solutions should start there. According to Article 3:6 of the WTO-Understanding "mutually agreed solutions to matters formally raised under the consultation and dispute settlement provisions of the covered agreements shall be notified to the DSB and the relevant Councils and Committees, where any member may raise any point relating thereto". Thus, GPA-signatories that have reached a bilateral solution-after authorization by the DSB to initiate such consultations-will have to notify the outcome to the DSB and the relevant Councils and Committees. The nature of the points that any member might raise is not defined.

17/ Emphasis added. 
What might happen in cases where a bilateral solution is reached and notified and some members think it is inconsistent with the Agreement? Article 3:5 of the WTO-Understanding is relevant here, where it is stated that all solutions to matters formally raised under the consultation and dispute settlement procedures shall be consistent with the Agreements and shall not nullify or impair benefits accruing to any other member, nor shall they impede the attainment of any objective of the covered agreements. Were one to interpret the two Articles in a way consistent with the obligations stemming from the multilateral context, the starting point should be that only panels can pronounce on the consistency of solutions reached. To judge otherwise would mean that consistency with the Agreement could be established at the bilateral level. This, however, could in turn provide an impediment to reaching bilateral solutions: Article 3:5 makes it clear that both systemic and trade interests could be taken into account. Theoretically, one could imagine a situation where panels could be requested to examine the consistency of remedies granted in a purely bilateral context that never reached the stage of panel procedure. What is not specified though, is to what extent third parties have standing before a panel in cases where bilateral solutions do not affect their trade interests. The crucial question in such cases will. consequently, be the consistency of the remedies agreed at the bilateral level with The GPA. This might constitute a future avenue for the WTO to embark on a serious-and unfortunately, still elusive-discussion on remedies in the WTO-context.

Concerning the time-limits applicable in dispute settlement, the GPA contains a particularity compared to the WTO-Understanding. Normal panel procedures should not exceed 6 months, with the possibility of extension up to 9 months in specific circumstances. In the GPA a clause is inserted stating that every effort shoul' '. . ade to limit the duration of panel proceedings to 4 months, and to 7 months at the very most. This is however, a best-endeavors clause, and, consequently, not legally binding.

\section{Exceptions}

Article XXIII contains an exhaustive list of legal grounds that can justify action by the signatories that is inconsistent with the Agreement. It is divided in two sub-paragraphs: (a) a national security exception; and (b) a list of other justifications as long as they are not being "applied in a manner which would constitute a means of arbitrary or unjustifiable discrimination between countries where the sime conditions prevail or a disguised restriction in international trade". The list covers measures: (i) necessary to protect public morals, order or safety; (ii) necessary to protect human, animal, plant life or health; (iii) necessary to protect intellectual property; (iv) relating to the products or services of handicapped persons, of philanthropic institutions or of prison labor. The GATT case law in this field will be of relevance, particularly insofar as the "necessity" principle has been incorporated as the appropriate criterion to judge actions taken by administrative authorities. 


\section{Developing Countries and Expanding Membership}

Membership of the GPA is quite limited. As mentioned previously, the Agreement has only 11 signatories (counting the EU as one). Although its Members account for a large share of global government procurement, the absence of broad-based participation is a source of concern. During the 1980s it was probably fair to say that much of the problem was the 'newness' of the GPA. But after 15 years, any uncertainty regarding the potential benefits of participation should have disappeared. The fact that Membership remains so limited suggests that non-Members perceive the costs of joining to outweigh the benefits. What is wrong with the GPA? What needs to be done to expand membership significantly? These questions are important, not just because there is a large 'hole' in the GATT, as public procurement constitutes a large source of demand for goods and services in most countries, but also because the General Agreement on Trade in Services (GATS) contains a provision calling for negotiations on government procurement of services to be initiated within two years of the entry into force of the WTO (i.e., January 1997). ${ }^{18}$

The obvious hypothesis in this regard is that non-members desire to be able to discriminate against foreign products or suppliers when awarding contracts. The fact that attempts were made to weaken the reach of the GPA's non-discrimination principles for developing countries suggests that this is indeed the case. Although in principle no discrimination is allowed in favor of domestic firms by covered entities, Article V:4 of the GPA allows developing countries to negotiate "mutually acceptable exclusions from the rules on national treatment with respect to certain entities, products, or services that are included in their lists of entities." Such negotiations may also be initiated ex post, after signing the agreement (Article V:S). Some scope therefore exists for, e.g., maintaining a price preference policy. However, the option is limited to certain entities, products or services, and is therefore inherently limited by the relative negotiating power of the country seeking accession.

Article XVI of the GPA allows developing countries, at the time of accession, to negotiate conditions for the use of offsets (e.g., domestic content requirements). This is a new provision, in that the Tokyo round agreement had only weak disciplines on the use of offsets. ${ }^{19}$ Under the new GPA offsets have been prohibited for industrialized countries, but remain possible for developing countries, thus explicitly allowing for de facto discrimination against foreign suppliers. However, offset requirements may only be used for qualification to participate in the procurement process and not as criteria for awarding contracts, and conditions are to be objective, clearly defined and non-discriminatory. Thus, although in principle allowed-if negotiated during accession-offsets may only be used as necessary

18/ See Hoekman (1994) for a brief review of the GATS.

19/ Art. V:14(h) stated, inter alia, that "entities should normally refrain from awarding contracts on the condition that the supplier provide offset ... Opportunities ... In the limited number of cases where such requisites are part of a contract, Parties concerned shall limit the offset to a reasonable proportion within the contract value .." 
conditions. If a firm offers local content that greatly exceeds the minimum required offered by its competitors, this may not be a factor in awarding contracts. As offset policies are very prevalent in developing countries. Article XVI appears to have been worded with the concerns of expanding participation in mind. As disciplines on offsets were weak under the old code, however, Article XVI does not constitute a new 'incentive' to join. ${ }^{30}$ Moreover, offsets are likely to be subject to negotiation. Israel has committed itself in its Annex that the maximum local content required is 35 percent for the first five years of the Agreement, dropping to 30 percent for the next four years, and 20 percent thereafter.

While offset requirements may be discriminatory in the sense that foreign firms are forced to use more local inputs than might be optimal from a profit maximizing perspective, they apply to locally established firms as well. A price preference policy discriminates more explicitly in favor of domestic firms. Interestingly, the choice that was made to allow offsets but prohibit price preferences is the opposite of what economic theory suggests regarding the welfare implications of these two policies. Although a case can be made in favor of price preferences in certain circumstances, domestic content provisions are usually inefficient instruments. As emphasized by McAfee and McMillan (1989), discriminatory procurement policies may be welfare improving, depending on the market structure of the industry and the type of good involved. In principle, nondiscriminatory procurement policies are therefore not necessarily optimal. Procurement costs may be lowered by pursuing price preferences if domestic firms have a competitive disadvantage in producing the product, and only a limited number of firms (foreign and domestic) bid for the contract. In the absence of a preference policy, in such a context foreign firms may exploit their cost advantage by bidding just below what they expect domestic firms to bid, which will be substantially higher than their actual cost. A price preference policy will force foreign firms to lower their bids, as it increases the effective competition from domestic firms. While the preference policy entails that the lowest bidder is not necessarily awarded the contract, thus implying higher costs to the government, on average the bids made by firms with a cost advantage may be lower than otherwise. Of course, if domestic firms do not have a cost disadvantage, no preferential policy should be pursued. ${ }^{21}$

Economic arguments for preferences only hold in a small numbers setting. If enough foreign and domestic firms are invited to bid, competition between them should ensure that the 'market' price is paid.

20/ The new GPA continues to contain rather extensive language regarding special and differential treatment of develoning countries (Art. V). Thus allowance is made for such countries not to abide by the GPA's nondiscrimination principles in order to safeguard the balance of payments; promote the development of local industry; or to support industrial units "so long as they are substantially dependent on government procurement." Although, these provisions are of a "best endeavors' nature in the sense that Parties to the GPA "shall, in the implementation and administration of this Agreement ... duly take into account" the foregoing 'needs', developing country signatories are given a substantial amount of discretion not to implement the GPA.

21/ It is ironic that the GPA does allow for discrimination against domestic firms, reflecting the adoption of the GATT's definition of national treatment. This requires that policies are "no less favorable" for foreign firms than what is applied to domestic ones, thus allowing preferential trearment for foreign products. 
In practice discriminatory government policies can be expected to be more costly than a national treatment policy, especially when no competitive tendering is sought or there is an absolute preference for domestic suppliers. Indeed, if foreign firms are excluded from bidding for contracts procurement, costs are likely to rise significantly. Without going into the pro's and con's of specific decision rules in this connection, ${ }^{22}$ what is relevant here is that criteria used in the enforcement of competition policy can be used to determine when to discriminate. As market structure is crucial, and this is the focus of competition enforcement, a competition office could be given the task to ascertain if the conditions calling for discrimination have been met in individual cases. The point is that reliance on a general rule of thumb (e.g., international competitive bidding for all contracts above a certain threshold) may not be appropriate. But, to diverge from this principle, information/analysis is needed. For a price preference scheme to reduce average procurement costs it is necessary to obtain information on the costs of foreign and domestic firms.

The impact of local content criteria on economic efficiency and welfare has been analyzed at length in the theoretical and policy-oriented economic literature. ${ }^{23}$ A general theme of this literature is that there is a need to investigate whether the specific rule that is employed attains the policy goal at least cost. In practice, the content requirements may not even be consistent with the underlying policy goal. A local content scheme that is intended to protect domestic producers of intermediates is usually an inferior instrument as alternatives exist that are less costly. Thus, it is w:ll known that production subsidies are generally the most efficient means of supporting a specific economic activity. Another theme is that policymakers should consider economy-wide implications. For example, while local content requirements protect domestic (regional) intermediate goods producers, this raises the costs of production for final good producers. By offering protection to producers of intermediates the probability increases that producers of final goods and services that use these intermediates will also petition for protection.

Local content rules are often used as schemes under which tariff preferences are provided to firms. Thus, if the content rule is met firms may be granted exemptions from-or reductions in-tariffs on imported inputs. A key difference between such schemes and local content (offset) requirements in the procurement setting is that in the latter case satisfying the offset requirement is a necessary condition for contesting the market. The firm cannot choose to pay the tariff (or a higher tariff). As is well known, such quantitative restrictions are much more distorting than price-based measures such as tariffs, or in the case at hand, price preferences. Indeed, there is a direct analogy between price preferences and offsets on the one hand, and tariffs and quotas on the other.

Tariffs are superior to quotas on economic grounds for many reasons. These include their greater transparency, less need for regulation and administration, and thus less scope for capture by vested

22/ Branco (1994) explores some of the practical implications of this result for the design of tender procedures.

23/ See, e.g., Vousden (1990). 
interests, and most importantly, the fact that a tariff will always allow the most efficient producers to maintain their competitive edge vis-a-vis other suppliers. Even if the necessary conditions for a price preference policy to he optimal have not been satisfied and a government simply desires to support local industry, price preferences will be a more efficient instrument than offsets. It is unfortunate therefore--if perhaps not surprising ${ }^{24}$--that negotiators chose to allow de facto quantitative restriction-like instruments instead of price-based measures.

The conditional-MFN approach based on reciprocal negotiation of entity lists ('market access') is another possible culprit underlying continued limited membership of the GPA. Parties to the Agreement have shown a tendency to define reciprocity on a sectoral basis. Absolute sectoral reciprocity has been a norm, i.e., a country that schedules its telecommunications provider(s) will seek to ensure that other signatories do so as well. This makes cross-sectoral (cross-entity and/or cross-product) tradeoffs more difficult, and reduces the potential gains from trade. For example, as mentioned earlier, a number of signatories to the new GPA introduced sectoral non-application and/or reciprocity provisions (naming the Parties of the GPA to which these exemptions applied) in their Annexes listing the procurement of services that would be subject to the GPA's rules. The objective of such provisions was the pursuit of a sectoral 'level playing field': the Parties making exceptions in their Annexes sought to ensure that market access conditions prevailing abroad would be at least as good as those implied by their own offer. Some participants viewed these developments-which reflected the move towards sectoral reciprocity in the GATS context-with serious misgivings. One signatory to the Tokyo round Agreement-Hong Kongfelt strongly enough about the resulting weakening of the GPA's nondiscrimination principle to refuse to sign the new GPA (Messerlin, 1994).

What might be done to expand membership of the GPA, and uitimately to multilateralize the Agreement? An argument can be made that the 'all or nothing' approach of the current GPA as regards discrimination is both too purist (not allowing price preferences) and not purist enough (allowing offsets; allowing sectoral reciprocity). Two possibilities arise: (1) pursue 'conditional tariffication': allow price preferences, subject to a determination that certain necessary conditions have been met (relating to market structure, number of bidders, etc.); and (2) allow for tariffication of procurement preferences more generally by developing countries. The first option is somewhat analogous to the pursuit of common competition policy disciplines, and may therefore be subject to the general arguments that can be raised against such efforts (see Hoekman and Mavroidis, 1994). However, as long as agreement can be reached regarding the economics of the issue, progress along this dimension may well be feasible without harmonization. Involvement of national competition-type bodies could be useful in the procurement area by establishing if a case exists for allowing the use of price preferences. If disagreements arise as regards determinations of these bodies, Members could invoke the GPA's dispute settlement procedures.

24/ When confronted with the choice policymakers often demonstrate a distinct preference for regulation of quantities rather than using more efficient price-based instruments. See e.g., Messerlin (1981) and Deardorff (1986). 
General tariffication is the more straightforward approach, of course, although not necessarily the optimal one from an economic perspective. ${ }^{25}$ It's advantage is the absence of any need to determine what the necessary conditions for using preferences are, and whether they have been met in particular instances. Even though clearly not 'first-best', allowing for price preferences could prove to be the simplest and most effective way of multilateralizing the GPA. Once countries have set/negotiated the implicit tariffs (price preferences) that they will apply, these price wedges can become the subject of periodic multilateral liberalization efforts (negotiating rounds). Tariffication can also do much to overcome the 'absolute' sectoral reciprocity constraint that has affected GPA talks. Once 'tariffs' have been set, negotiators can follow GATT's well-established techniques of incremental liberalization, what Bhagwati (1988) has called the 'first-difference' approach to reciprocity.

In allowing for discrimination through tariffication care should be taken that signatories do not engage in opportunistic behavior by setting rates at stratospheric levels. But an analogy with agriculture is perhaps appropriate here. Although tariffs may be bound at high levels, this may be worth it in terms of subjecting this sector of activity to multilateral rules, especially if in the process the use of quantitative measures (quotas in agriculture, offsets here) becomes circumscribed.

The potential gains from trade are pretty clear. Developing countries offer potential markets for current signatories, whereas governments that are concerned with minimizing their budgetary outlays have a stake in adopting procurement practices that maximize national welfare. As in other areas, the key issue appears to be one of information: often it may not be clear to policymakers what procurement policy is the most beneficial. As is the case for services as regards the costs and benefits of regulatory regimes, very little is known about the way that goods and services are procured by most governments, and the opportunity costs of current practices. Indeed, often basic information on the practices and procedures that are pursued are not readily available. Examples include the share of contracts that are awarded to foreign suppliers; and the conditions that are actually imposed in terms of local content or price preferences on a case-by-case basis.

A 'transparency' body could therefore make a very useful contribution to policy formation by evaluating procurement policies and practices. An obvious step in this direction would be to expand the Trade Policy Review Mechanism (TPRM) to procurement for those WTO Members that have signed the GPA. The GPA already requires Parties to report statistics to the Committee that allow for an analysis of sourcing practices. However, these data are not published, and have not been used for analytical purposes. As was the case with the acceptance of the TPRM in 1988, although most countries will not

25/ See Deardorff and Stern (1985) and Herander (1982) for an analysis of the tariff-equivalent of price preferences. In general a 10 percent preference may not be equivalent to a 10 percent tariff for an entity because entrepreneurs in the country have an incentive to import goods, process them enough to be considered 'local' and then sell them to the entity. For the economy as a whole, a 10 percent preference will only be equivalent to a 10 percent tariff if the Government entity is the only buyer of the product. 
have much desire to subject themselves to a transparency-based review of their procurement policies, the benefit of obtaining information on trading partners may outweigh the perceived cost of being subjected to review as well.

Before concluding, the question should be posed whether tariffication will be acceptable to OECD and other high income countries that have objections to the GPA. Of the OECD countries, Australia, Mexico, New Zealand and Turkey are not members of the GPA. Australia and New Zealand appear not to have joined because they wish to maintain price preference policies (MacAfee and McMillan, 1989). The same is probably true for Mexico and Turkey. Such countries could therefore support tariffication. This may not be the case for countries that favor nondiscrimination. Singapore, a signatory of the Tolkyo round agreement, has not become a member of the no-: GPA. Hong Kong, another member of the Tokyo round code, also refused to sign, in part because it felt that the new GPA had weakened its nondiscrimination requirements too much (Messerlin, 1994). ${ }^{26}$ Tariffication will make the GPA substantially less 'pure', and thus may not please those WTO Members that already perceive the Agreement as being too weak. The elimination of the offset loophole and the a substantial expansion of merrhership might, however, provide a counterweight for such Members.

\section{Concluding Remarks}

The coverage of the GPA was significantly expanded as a result of the negotiations that were held during the Uruguay round. Its enforcement provisions were strengthened, in particular by the introduction of a bid-protest challenge mechanism. These are very innovative for the GATT-MTN system in that they allow private parties (firms) to invoke the GPA before national courts. In the process, however, potential problems have been created, due to the possibility of diverging interpretations of the GPA by domestic courts. Time will tell whether this possibility is realized. Much was done to enhance transparency of procurement practices of signatories. Further strengthening could be achieved by requiring that the publication of contract awards (already required) include a brief motivation of decisions (presently not required). Multilateral 'surveillance' of procurement practices could also be strengthened substantially by giving the WTO Secretariat the mandate to analyze the statistics on procurement that are submitted to the Committee each year.

Membership of the GPA remains limited. Indeed, at the entry into force of the new GPA there may be fewer signatories than at the beginning of the Uruguay Round. Inducing greater participation is

26/ The new GPA gives Hong Kong and Korea until January 1, 1997 to apply the Agreement. However, Hong Kong decided in April 1994 (just one week before the Marrakesh meeting formally concluding the Uruguay Round) not to join. It can be noted that the EU has stated in its annexes that GPA rules for services procurement will only apply to Spanish entities as of January 1, 1997, and for Greek and Portuguese entities as of January 1, 1998. 
important as procurement is the last major 'hole' in the GATT. Addressing the issue of 'multilateralizing' the GPA should be given priority by policymakers. Public procurement constitutes a large source of demand for goods and services in most countries. Getting domestic procurement policies 'right' therefore can have large welfare effects. At the same time, improving developing country access to global procurement markets could help to induce Government's to adopt multilateral rules if these can be shown to be in their interests. Perhaps the most immediate source of urgency stems from the General Agreement on Trade in Services (GATS), which contains a provision calling for negotiations on government procurement of services to be initiated within two years of the entry into force of the WTO (i.e., January 1997). The rules and procedures that are negotiated will be important in determining the potential for growth in developing country exports of services. The fact that the GPA was somewhat 'infected' by the GATS-which takes a sector-specific approach to liberalization--through the introduction of sectoral non-application and reciprocity conditions is worrisome in this connection.

Pursuit of tariffication could be an avenue through which membership in the GPA can be expanded in the future. In the process, the GPA could be improved from an economic perspective by eliminating current loopholes that allow for measures with quota-like effects, and weakening the incentives to pursue 'absolute' reciprocity. More generally, research efforts are required to identify possible approaches towards extending muitilateral disciplines for procurement of goods and services that will be beneficial to developing countries, and thus be helpful in formulating negotiating positions and strategies. Such research should emphasize two issues. The first is to anaiyze in greater depth the economics of the GPA's rules and disciplines, investigate what the impact of the Agreement has been, and explore what might be done to expand its membership. The second pertains to obtaining information on current procurement policies in non-member countries and the quantitative importance of prucurement markets in major selected OECD and developing countries. 


\section{References}

Bhagwati, Jagdish. 1988. Protectionism. Cambridge: MIT Press.

Blank, Annet. 1994. "Government Procurement from a Multilateral Trade Perspective: The New Agreement on Government Procurement in the GATT," mimeo.

Bourgeois, Jacques. 1982. "The Tokyo Round Agreements on Technical Barriers and on Government Procurement in International and EEC Perspective," Common Market Law Review, 19, 5-33.

Branco, Fernando. 1994. "Favoring Domestic Firms in Procurement Contracts," Journal of International Economics, 37:65-80.

Deardorf, Alan V. 1987. "Why do Governments Prefer Nontariff Barriers?" Carnegie Rochester Conference Series on Public Policy. Spring.

Deardorff, Alan and Robert Stern. 1985. Methods of Measurement of Non-Tariff Barriers. Geneva: UNCTAD.

Herander, Mark. 1982. "The Impact of Government Procurement Price Discrimination and Its Equivalence with the Tariff," Weltwirtschaftliches Archiv, 118:525-45.

Hoekman, Bernard M. 1994. "The General Agreement on Trade in Services," in The New World Trading System: Readings. Paris: OECD.

Hoekman, Bernard M. and Petros C. Mavroidis. 1994. "Competition, Competition Policy and the GATT," The World Economy, 17:121-150.

Hoekman, Bernard M. and Robert M. Stern. 1993. "An Assessment of the Tokyo Round Agreements and Arrangements," in Robert Stern (ed.), The Multilateral Trading System: Analysis and Options for Change. Ann Arbor: University of Michigan Press.

Jackson, John H. 1989. The World Trading System: Law and Policy of International Economic Relations. Cambridge, MA.: MIT Press.

McAfee, R. Preston and John McMillan. 1989. "Government Procurement and International Trade," Journal of International Economics, 26:291-308.

Mavroidis, Petros C. 1993. "Government Procurement Agreement: The Trondheim Case," Aussenwirtschaft, 48:77-94.

Messerlin, Patrick A. 1981. "The Political Economy of Protection: The Bureaucratic Case," Weltwirtschaftliches Archiv, 117:469-96.

Messerlin, Patrick. 1994. "Agreement on Government Procurement," in The New World Trading System: Readings. Paris: OECD. 
Petersmann, Ernst-Ulrich. 1991. "Violation Complaines and Non-violation complaints in Public International Trade Laws," German Ycarbook of International Law, 34, 175-229.

Vousden, Neil. 1990. The Economics of Trade Protection. Cambridge: Cambridge University Press. 
Table 1: Thresholds in Annexes 1,2 and 3 of the GPA

Special Drawing Rights (SDR) SDR 1 equals approx \$US 1.4 (1994)

\begin{tabular}{|c|c|c|c|c|c|c|c|c|c|c|c|}
\hline & Austria & Canada & EC & Finland & Israel & Japan & Korea & Norway & Sweden & $\mathrm{CH}$ & US \\
\hline $\begin{array}{l}\text { Annex } 1 \\
\text { Goods } \\
\text { Services except } \\
\text { construction service } \\
\text { construction services }\end{array}$ & $\begin{array}{l}130,000 \\
130,000 \\
5,000,000\end{array}$ & $\begin{array}{l}130,000 \\
130,000 \\
5,000,000\end{array}$ & $\begin{array}{l}130,000 \\
130,000 \\
5,000,000\end{array}$ & $\begin{array}{l}130,000 \\
130,000 \\
5,000,000\end{array}$ & $\begin{array}{l}130,000 \\
130,000 \\
8,500,000\end{array}$ & $\begin{array}{l}130,000 \\
130,000 \\
4,500,000 \\
\text { Architect. } \\
\text { services: } \\
450,000\end{array}$ & $\begin{array}{l}130,000 \\
130,000 \\
5,000,000\end{array}$ & $\begin{array}{l}130,000 \\
130,000 \\
5,000,000\end{array}$ & $\begin{array}{l}130,000 \\
130,000 \\
5,000,000\end{array}$ & $\begin{array}{l}130,000 \\
130,000 \\
5,000,000\end{array}$ & $\begin{array}{l}130,000 \\
130,000 \\
5,000,000\end{array}$ \\
\hline $\begin{array}{l}\text { Annex } 2 \\
\text { Goods } \\
\text { Services except } \\
\text { construction Service } \\
\text { Construction Services }\end{array}$ & $\begin{array}{l}200,000 \\
200,000 \\
5,000,000\end{array}$ & $\begin{array}{l}355,000 \\
355,000 \\
5,000,000\end{array}$ & $\begin{array}{l}200,000 \\
200,000 \\
5,000,000\end{array}$ & $\begin{array}{l}200,000 \\
200,000 \\
5,000,000\end{array}$ & $\begin{array}{l}250,000 \\
250,000 \\
8,500,000\end{array}$ & $\begin{array}{l}200,000 \\
200,000 \\
15,000,000 \\
\text { Architect. } \\
\text { services: } \\
1,500,000\end{array}$ & $\begin{array}{l}200,000 \\
200,000 \\
15,000,000\end{array}$ & $\begin{array}{l}200,000 \\
200,000 \\
5,000,000\end{array}$ & $\begin{array}{l}200,000 \\
200,000 \\
5,000,000\end{array}$ & $\begin{array}{l}200,000 \\
200,000 \\
5,000,000\end{array}$ & $\begin{array}{l}355,000 \\
355,000 \\
5,000,000\end{array}$ \\
\hline $\begin{array}{l}\text { Annex } 3 \\
\text { Goods } \\
\text { Services except } \\
\text { construction services } \\
\text { Construction services }\end{array}$ & $\begin{array}{l}400,000 \\
400,000 \\
5,000,000\end{array}$ & $\begin{array}{l}355,000 \\
355,000 \\
5,000,000\end{array}$ & $\begin{array}{l}400,000 \\
400,000 \\
5,000,000\end{array}$ & $\begin{array}{l}400,000 \\
400,000 \\
5,000,000\end{array}$ & $\begin{array}{l}355,000 \\
355,000 \\
8,500,000\end{array}$ & $\begin{array}{l}130,000 \\
130,000 \\
\text { I5,000,000 } \\
\text { Architect. } \\
\text { services: } \\
450,000\end{array}$ & $\begin{array}{l}450,000 \\
15,000,000\end{array}$ & $\begin{array}{l}400,000 \\
400,000 \\
5,000,000\end{array}$ & $\begin{array}{l}400,000 \\
400,000 \\
5,000,000\end{array}$ & $\begin{array}{l}400,000 \\
400,000 \\
5,000,000\end{array}$ & $\begin{array}{l}400,000 \\
400,000 \\
5,000,000\end{array}$ \\
\hline
\end{tabular}

Annex 1: Central government entities

Annex 2: $\quad$ Sub-ceniral government entities

Annex 3: All other entities which procure in accordance with the Agreement, in general public enterprises or public authorities or public authorities such as Utilities. 
Title

WPS1411 Income Inequality, Welfare, and Poverty: An Illustration Using Ukrainian Data

WPS1412 Foreign Technology Imports and Economic Growth in Developing Countries

WPS1413 Endogenous Distortions in Product and Labor Markets

WPS1414 The World Bank and Legal Technical Assistance: Initial Lessons

WPS1415 China's GDP in U.S. Dollars Based on Purchasing Power Parity

WPS1416 Informal Regulation of Industrial Pollution in Developing Countries: Evidence from Indonesia

WPS1417 Uncertainty and Global Warming: An Option-Pricing Approach to Policy

WPS1418 The Impact of Labor Market Regulations

WPS1419 Industry Structure and Regulation

WPS1420 Legislative Frameworks Used to Foster Petroleum Development

WPS1421 Distribution of Income and the Income Zeljko Bogetic Tax Burden in Bulgaria

WPS1422 Efficiency in Bulgaria's Schools: A Nonparametric Study

WPS1423 The Role of Commercial Banks in Enterprise Restructuring in Central and Eastem Europe

WPS1424 Terms-of-Trade Shocks and Optimal investment: Another Look at the Laursen-Metzler Effect Fareed M. A. Hassan

Author

Nanak Kakwani

Xiaoming Zhang

Heng-lu Zou

Martin Rama

Guido Tabellini

The World Bank

Legal Department

Ren Ruoen

Chen Kai

Sheoli Pargal

David Wheeler

Andrea Baranzini

Marc Chesney

Jacques Morisset

Lyn Squire

Sethaput Suthiwart-

Narueput

Martin C. Stewart-Smith

William T. Onorato

Zeljko Bogetic

Sajal Chattophadyay

Millard Long

Izabela Rutkowska

Luis Serven

February 1995

37471
February 1995

February 1995

E. Khine

Contact

for paper

G. Evans

85783

C. Jones

37754

S. Fallon 38009

K. Mathemová 82782

E. O'Rielly-Campbell 33707

E. Schaper 33457

C. Dell 85148

G. Bayard

37460

N. James

82758

W. Onorato 81611

F. Smith 36072

F. Smith 36072

R. Gamer

37670

February 1995 
Tite

WPS1425 On the Intersectoral Migration of Agricultural Labor

WPS1426 Russian Unemployment: Its Magnitude, Characteristics, and Regional Dimensions

WPS1427 Corporate Governance and Equity Prices: Evidence from the Czech and Slovak Republics

WPS1428 Short-Term Supply Response to a Devaluation: A Model's Implications for Primary Commodity-Exporting Developing Countries

WPS1429 The World Trade Organization's Agreement on Government Procurement: Expanding Disciplines, Declining Membership?
Author

Donald Larson

Yair Mundiak

Simon Commander

Ruslan Yemtsov

Stign Claessens

Bruno Boccara

Fabien Nsengiyumva

Bemard M. Hoekman

Petros C. Mavroidis
Date

February 1995

February 1995

February 1995

March 1995
F. Hatab

38535

Contect

for paper

J. Jacobson

33710

V. Reid

35195

F. Hatab 35835

M. Pfeiffenberger 34963 
